\title{
OPTIMAL VLSI ARCHITECTURAL SYNTHESIS
}

Area, Performance and Testability 


\title{
THE KLUWER INTERNATIONAL SERIES IN ENGINEERING AND COMPUTER SCIENCE
}

\author{
VLSI, COMPUTER ARCHITECTURE AND \\ DIGITAL SIGNAL PROCESSING \\ Consulting Editor \\ Jonathan Allen
}

Latest Titles

Low-Noise Wide-Band Amplifiers in Bipolar and CMOS Technologies, Z.Y.Chang, W.M.C.Sansen, ISBN: 0-7923-9096-2

Iterative Identification and Restoration of Images, R. L.Lagendijk, J. Biemond ISBN: 0-7923-9097-0

VLSI Design of Neural Networks, U. Ramacher, U. Ruckert ISBN: 0-7923-9127-6

Synchronization Design for Digital Systems, T. H. Meng ISBN: 0-7923-9128-4

Handware Annealing in Analog VLSI Neurocomputing, B. W. Lee, B. J. Sheu ISBN: 0-7923-9132-2

Neural Networks and Speech Processing, D. P. Morgan, C.L. Scofield ISBN: 0-7923-9144-6

Silicon-on-Insulator Technology: Materials to VLSI, J.P. Colinge ISBN: 0-7923-9150-0

Microwave Semiconductor Devices, S. Yngvesson ISBN: 0-7923-9156-X

A Sunvey of High-Level Synthesis Systems, R. A. Walker, R. Camposano ISBN: 0-7923-9158-6

Symbolic Analysis for Automated Design of Analog Integrated Circuits,

G. Gielen, W. Sansen, ISBN: 0-7923-9161-6

High-Level VLSI Synthesis, R. Camposano, W. Wolf, ISBN: 0-7923-9159-4

Integrating Functional and Temporal Domains in Logic Design: The False Path Problem and its Implications, P. C. McGeer, R. K. Brayton, ISBN: 0-7923-9163-2

Neural Models and Algorithms for Digital Testing, S. T. Chakradhar,

V. D. Agrawal, M. L. Bushnell, ISBN: 0-7923-9165-9

Monte Carlo Device Simulation: Full Band and Beyond, Karl Hess, editor ISBN: 0-7923-9172-1

The Design of Communicating Systems: A System Engineering Approach,

C. J. Koomen

ISBN: 0-7923-9203-5

Parallel Algorithms and Architectures for DSP Applications,

M.A. Bayoumi, editor ISBN: 0-7923-9209-4

Digital Speech Processing: Speech Coding, Synthesis and Recognition,

A. Nejat Ince, editor

ISBN: $0-7923-9220-5$

Assessing Fault Model and Test Quality, Kenneth M. Butler, M. Ray Mercer ISBN: 0-7923-9222-1 


\title{
OPTIMAL VLSI ARCHITECTURAL SYNTHESIS
}

\section{Area, Performance and Testability}

\author{
Catherine H. Gebotys \\ and \\ Mohamed I. Elmasry \\ University of Waterloo
}

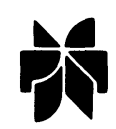

Springer Science+Business Media, LLC 


\section{Library of Congress Cataloging-in-Publication Data}

\section{Gebotys, Catherine H.}

Optimal VLSI architectural synthesis : area, performance, and testability / Catherine H. Gebotys and Mohamed I. Elmasry.

p. $\mathrm{cm}$. -- (The Kluwer international series in engineering and computer science. VLSI, computer architecture, and digital signal processing)

Includes bibliographical references and index.

ISBN 978-1-4613-6797-0 ISBN 978-1-4615-4018-2 (eBook)

DOI 10.1007/978-1-4615-4018-2

1. Computer architecture. 2. Integrated circuits--Very large scale integration. I. Elmasry, Mohamed I., 1943- . II. Title. III. Series.

QA76.9.A73G42 1992

004.2 '2--dc20

\section{Copyright 1992 Springer Science+Business Media New York} Originally published by Kluwer Academic Publishers in 1992

Softcover reprint of the hardcover 1st edition 1992

All rights reserved. No part of this publication may be reproduced, stored in a retrieval system or transmitted in any form or by any means, mechanical, photo-copying, recording, or otherwise, without the prior written permission of the publisher, Springer Science+ Business Media, LLC.

Printed on acid-free paper. 
Robert Joseph and Kathleen Vanessa Gebotys

and

Elizabeth, Carmen, Samir, Nadia and Hassan Elmasry 


\section{Table of Contents}

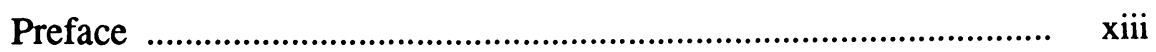

PART I: INTRODUCTION _........................................................ 1

1. GLOBAL VLSI DESIGN CYCLE .............................................. 3

1.1 VLSI DESIGN CYCLE ........................................................... 4

1.2 HYBRID SYSTEMS DESIGN ............................................. 10

1.3 IMPACT OF TECHNOLOGIES …………………………..... 12

1.4 TEST CONSIDERATIONS ................................................ 14

1.5 BOTTLENECKS AND OPEN ISSUES ……………………..... 17

1.6 FOCUS OF TEXT ………………………………………….... 19

2. BEHAVIORAL AND STRUCTURAL INTERFACES

2.1 INPUT TO AN ARCHITECTURAL SYNTHESIZER

2.2 INTERFACE PRIMITIVES FOR EXTERNAL PROCESSES

2.3 OUTPUT PRIMITIVES FROM AN ARCHITECTURAL SYNTHESIZER ..................................................................... 31

PART II: REVIEW AND BACKGROUND .................................. 37

3. STATE OF THE ART SYNTHESIS ……………………........... 39

3.1 TERMINOLOGY AND SUBTASK DEFINITIONS

3.2 HIGH LEVEL TRANSFORMATIONS .................................. 43

3.3 INDEPENDENT SUBTASK OPTIMIZATION ...................... 45 
3.3.1 Scheduling

3.3.2 Resource Allocation

3.4 ITERATIVE AND SIMULTANEOUS APPROACHES

3.5 MATHEMATICAL APPROACHES .................................... 55

3.5.1 Branch and Bound ....................................................... 55

3.5.2 Simulated Annealing ......................................................... 57

3.5.3 Makespan Scheduling ................................................... 58

3.5.4 Feasibility Models ........................................................... 58

3.6 TIMING CONSTRAINED SYNTHESIS ................................. 59

3.7 COST FUNCTIONS FOR DESIGN EVALUATION

4. INTRODUCTION TO INTEGER PROGRAMMING

4.1 APPLICATIONS AND MODELS …....................................... 64

4.2 SOLUTION OF UNSTRUCTURED IPs …............................ 66

4.3 POLYHEDRAL APPROACHES TO SOLVING IPS

4.4 THE NODE PACKING PROBLEM ..................................... 73

4.5 THE KNAPSACK PROBLEM ............................................ 78

PART III: OPTIMAL ARCHITECTURAL SYNTHESIS WITH INTERFACES …...................................................... 81

5. A METHODOLOGY FOR ARCHITECTURAL SYNTHESIS ............................................................................... 83

5.1 REQUIREMENTS FOR HIGH LEVEL SYNTHESIS TOOLS .......................................................................... 83

5.2 HIGH LEVEL METHODOLOGY ........................................ 85 
5.3 OASIC METHODOLOGY ................................................. 88

5.4 AN INTRODUCTION TO OASIC ........................................ 90

5.5 OASIC TERMINOLOGY, ASSUMPTIONS, AND

PREPROCESSING .............................................................. 92

5.5.1 Terminology .............................................................. 92

5.5.2 Assumptions .................................................................. 94

5.5.3 Preprocessing ................................................................... 94

6. SIMULTANEOUS SCHEDULING, AND SELECTION AND ALLOCATION OF FUNCTIONAL UNITS ......................... 97

6.1 THE FORMAL MODEL ….................................................... 98

6.2 COST FUNCTIONS ........................................................ 105

6.3 FUNCTIONAL UNIT TYPE SELECTION ........................... 106

7. OASIC: AREA-DELAY CONSTRAINED ARCHITEC-

TURAL SYNTHESIS ............................................................. 109

7.1 THE PRECEDENCE CONSTRAINED SCHEDULING

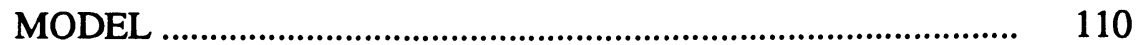

7.2 FUNCTIONAL UNIT ALLOCATION ............................... 111

7.3 REGISTER ALLOCATION ............................................... 111

7.4 BUS ALLOCATION ......................................................... 114

7.5 COST FUNCTIONS ....................................................... 119

7.6 APPLICATION SPECIFIC TIGHTENING OF CONSTRAINTS ...................................................................... 120

8. SUPPORT FOR ALGORITHMIC CONSTRUCTS ................. 123

8.1 CONDITIONAL CODE ................................................... 123

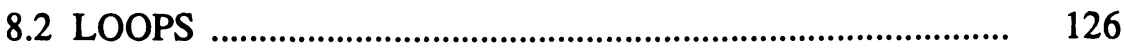

8.3 FUNCTIONAL PIPELINING ............................................ 126 
9. INTERFACE CONSTRAINTS

9.1 GENERAL INTERFACE: MINIMUM AND MAX-

IMUM TIMING CONSTRAINTS

9.2 ANALOG INTERFACE: FIXED TIMING CON-

STRAINT

9.3 ASYNCHRONOUS INTERFACE

9.4 UNKNOWN UNBOUNDED DELAYS

9.5 COMPLEX TIMING CONSTRAINTS

10. OASIC SYNTHESIS RESULTS

10.1 ELLIPTICAL WAVE FILTER

10.1.1 Structured Model

10.1.2 Area-Delay Optimized

10.2 NEURAL NETWORK ALGORITHM

10.3 CONDITIONAL CODE EXAMPLE

10.4 ANALOG AND ASYNCHRONOUS INTERFACE EXAMPLES

10.6.1 Analog Interface

10.6.2 Asynchronous Interface

\section{PART IV: TESTABLE ARCHITECTURAL SYNTHESIS}

11. TESTABILITY IN ARCHITECTURAL SYNTHESIS

11.1 DESIGN AND TEST

11.1.1 Choices in Design and Test

11.2 APPROACHES TO TESTABILITY 
11.2.2 Design Modifications for Testability

11.3 PREVIOUS RESEARCH IN DESIGN FOR TEST

200

\subsection{APPROACHES TO TEST WITH SYNTHESIS}

202

11.4.1 Previous Research

202

11.4.2 Commercial Systems

203

11.5 INADEQUACIES OF CURRENT SYNTHESIS WITH TEST

11.5.1 Feedback 204

11.5.2 Integration 205

11.5.3 Constraint Estimation 205

12. THE CATREE ARCHITECTURAL SYNTHESIS WITH TESTABILITY

12.1 PROBLEM DESCRIPTION 208

12.2 COMPARISON WITH PREVIOUS RESEARCH

12.3 TWO SYNTHESIS WITH TEST METHODOLOGIES:

CATREE \& CATREE2

12.4 CATREE DESIGN SYNTHESIS STAGES

12.4.1 Input Specification

12.4.2 Design Allocation

12.4.3 CATREE Area and Delay Estimates 224

12.4.4 Test Incorporation 226

12.4.5 Feedback 231

12.5 CATREE SYNTHESIS RESULTS 235 12.6 CATREE DISCUSSION 
12.7.1 Tree Formation and Functional Unit Binding

12.7.2 Test Incorporation ........................................................ 245

12.7.3 (Test) Register and Bus Binding .................................. 248

12.7.4 Feedback ................................................................. 250

12.8 CATREE2 EXPERIMENTS ........................................... 251

12.9 CATREE2 DISCUSSION ................................................ 254

PART V: SUMMARY AND FUTURE RESEARCH .

13. SUMMARY AND FUTURE RESEARCH ............................ 261

13.1 OASIC SUMMARY ...................................................... 261

13.2 CATREE SUMMARY …............................................. 266

13.3 FUTURE EXTENSIONS _.............................................. 267

13.4 CONCLUDING REMARKS ....................................... 269

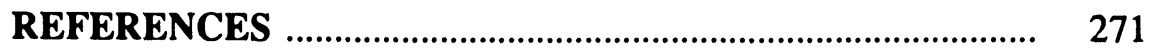

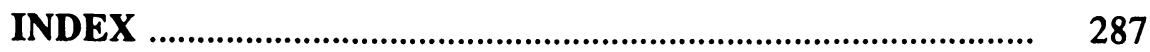




\section{PREFACE}

Although research in architectural synthesis has been conducted for over ten years it has had very little impact on industry. This in our view is due to the inability of current architectural synthesizers to provide area-delay competitive (or "optimal") architectures, that will support interfaces to analog, asynchronous, and other complex processes. They also fail to incorporate testability. The OASIC (optimal architectural synthesis with interface constraints) architectural synthesizer and the CATREE (computer aided trees) synthesizer demonstrate how these problems can be solved.

Traditionally architectural synthesis is viewed as NP hard and therefore most research has involved heuristics. OASIC demonstrates by using an IP approach (using polyhedral analysis), that most input algorithms can be synthesized very fast into globally optimal architectures. Since a mathematical model is used, complex interface constraints can easily be incorporated and solved.

Research in test incorporation has in general been separate from synthesis research. This is due to the fact that traditional test research has been at the gate or lower level of design representation. Nevertheless as technologies scale down, and complexity of design scales up, the push for reducing testing times is increased. On way to deal with this is to incorporate test strategies early in the design process. The second half of this text examines an approach for integrating architectural synthesis with test incorporation. Research showed that test must be considered during synthesis to provide good architectural solutions which minimize 
area delay cost functions.

Though originally developed separately, OASIC and CATREE can be integrated so that OASIC simultaneously schedules and allocates the architecture and CATREE performs binding (and reallocating) of the architecture for testability.

Part I introduces the motivation and current open problems with high level CAD. Part II provides the necessary background material on architectural synthesis and integer programming. This part includes a definition of problems in both areas and a brief review of previous approaches to solving these problems. Part III outlines the OASIC methodology, models, the solution techniques used, and some synthesized results. Part IV outlines the CATREE methodology, the algorithms and data structures used and some synthesized results. Part V provides a brief discussion and concluding remarks conceming how we will interface with CAD tools of the future.

The book can be used at the senior undergraduate and graduate levels in courses dealing with computer architectures, computer organization, VLSI design, computer-aided design, VLSI digital signal processing, testing, or integer programming. It will be also of value to resesarchers dealing with these topics.

C.H. Gebotys

M.I. Elmasry

Waterloo, Ontario, Canada 